Esta revista forma parte del acervo de la Biblioteca Jurídica Virtual del Instituto de Investigaciones Jurídicas de la UNAM http://www.juridicas.unam.mx/

https://biblio.juridicas.unam.mx/bjv

https://revistas.juridicas.unam.mx/

NOTES

Universidad Nacional Autónoma de México, IIJ-BJV, 2021 https://revistas.juridicas.unam.mx/index.php/mexican-law-review/issue/archive 


\title{
MEXICAN NOTARY PUBLICS IN THE FIGHT AGAINST MONEY LAUNDERING
}

\author{
Florencia Aurora LedESMA LoIs*
}

\begin{abstract}
The main task of the Mexican notary is to provide, at the request of individuals, certainty and security to legal acts and facts through the exercise of public trust, which is characterized by the specialization of its function and the expertise required to perform the activity. However, in modern times, its obligations have been expanded to include assisting national and international authorities in the fight against the crime of money laundering and its provenance, such as drug trafficking, extortion, theft, corruption, embezzlement, tax and investment fraud, terrorism and its financing, among others. Therefore, the main objective of this note is to analyze the mandatory burden on notaries within the national legal framework, which has been established in accordance with globally imposed demands to combat the perpetration of such illegal behaviors. Similarly, the possible penalties that may apply in the event of non-compliance with the applicable provisions shall be examined from a critical and theoretical perspective. The research problem is addressed from a dogmatic and formalist methodology consistent with the subject of study, providing an explanation based on the factual, regulatory, and axiological dimensions.
\end{abstract}

Keywords: Money laundering, illicit proceeds, Notary Public, mandatory burden.

RESUMEN: La principal labor del notariado mexicano es brindar a solicitud de los particulares, certeza y seguridad jurídica a los hechos y actos jurídicos por medio del ejercicio de la fe pública, la cual se caracteriza por la especialidad de su función y por la pericia requerida para el desarrollo de la actividad. Sin embargo, en épocas actuales, se advierte la ampliación de sus obligaciones esenciales con la finalidad de auxiliar a las autoridades nacionales e internacionales en el combate contra el delito de lavado de dinero y sus precedentes, tales como el tráfico de drogas, extorsión, robo, corrupción, malversación de

* PhD in Legal Sciences (PNPC), Master in Law, Notarial Law Specialist. Professor at the Autonomous University of Queretaro, UAQ. Email: ledesmalois10@gmail.com. This note was written with the collaboration of PhD Alina del Carmen Nettel Barrera (SNI I). 
fondos, fraude fiscal y de inversión, terrorismo y su financiamiento, entre otros. Es por ello por lo que el principal objetivo de la presente nota es analizar la carga obligacional establecida a los notarios dentro del marco jurídico nacional, la cual se ha determinado en concordancia con las exigencias que a nivel global han sido impuestas para luchar contra la comisión de dichas conductas ilicitas. Asimismo, se examinarán las posibles sanciones a las que pueden ser acreedores en caso de inobservancia de las disposiciones aplicables desde una perspectiva crítica y con fundamento teórico. El problema de investigación se aborda desde una metodología dogmático-formalista coherente con el objeto de estudio, realizando una explicación a partir de las dimensiones fácticas, normativas y axiológicas.

Palabras clave: Lavado de dinero, recursos ilícitos, Notario Público, carga obligacional.

Table of Contents

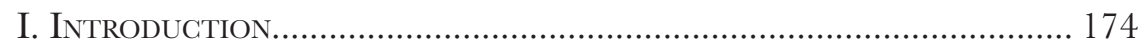

II. Anti-Money Laundering Legal Framework ................................. 175

III. The Role of the Mexican Notary in the Fight Against the Grime of Money Laundering …............................................. 179

IV. Dimensions of the Problem and its Turning Points ..................... 183

V. Gonclusions .......................................................................... 185

\section{INTRODUCTION}

This note centers on the analysis of the mandatory burden imposed on the Mexican Notariat. This burden arises from the legal framework of anti-money laundering and the possible penalties that may be applied in the event them do not comply with the provisions establishing mechanisms to prevent and minimize the use of illicit proceeds.

The importance of this note lies in the need to identify, first of all, the process of money laundering and the related felonies that have global effects, as well as to give an in-depth explanation of the administrative obligations set out to the Notariat to assist the authorities in the fight against such crimes.

The hypothesis presented in this note is that the mandatory burden of anti-money laundering imposed to the Mexican Notariat exceeds the material possibility of compliance, among other reasons, because of the lack of technological and human infrastructure, putting notaries in a difficult situation regarding the proper exercise of their duties and making it difficult to provide the service under different scenarios.

The problem is addressed from a dogmatic-formalist methodology, as it provides consistent elements with which to study the phenomenon. 


\section{Anti-Money Laundering Legal Framework}

An outline of the global legal framework for anti-money laundering and principle crime-fighting organizations will be drawn in this chapter, starting with the Financial Action Task Force $(\mathrm{FATF})^{1}$ which is an inter-governmental policy-making body with the ministerial mandate to establish international standards for combating crimes committed with illicit resources. This organization defines what "money laundering" is: the process through which the origin of illegally-obtained funds are disguised, thus allowing criminals to enjoy profits without jeopardizing their source. ${ }^{2}$ Such unlawful conduct involves the commission of other crimes, which have become mainstream topics on the global agenda since its practice compromises the economy, ${ }^{3}$ as well as the national and international security of the countries. ${ }^{4}$

In this regard and as the most important international group that works together with governments, policy-makers and citizens to establish standards and solutions for a range of social and economic challenges, ${ }^{5}$ the Organization for Economic Co-operation Development (OECD) explains that money laundering must be stopped because criminals all around the world accumulate significant sums of money by committing crimes such as drug and human trafficking, theft, investment fraud, extortion, corruption, embezzlement and tax fraud, posing a serious threat to the economy and the integrity of financial institutions. ${ }^{6}$

1 Financial Action Task Force, An introduction to the FATF and its work, FATF-GAFI (2010), available at $h$ ttp://wrerc:fatfgafi.org/media/fatf/documents/brochuresannualreports/Introduction\% 20 to \% 20the\%2 FATF.pdf.

2 Financial Action Task Force, Official Website, What is money Laundering? FATF-GAFI (2020), available at https//werere:fatf-gafi.org/faq/moneylaundering/.

3 "Money laundering causes a diversion of resources to less productive areas of the economy which in turn depresses economic growth. The possible social and political costs of money laundering, if left unchecked or dealt with ineffectively, are serious. The economic and political influence of criminal organizations can weaken the social fabric, collective ethical standards, and ultimately the democratic institutions of society". Vandana A. Kumar, Money Laundering: Concept, Significance and its Impact, 2 Eur. Jour. Bus. Man. 115 (2012), available at https://core. ac.uk/download/pdf/234624157.pdf.

4 "Money laundering poses international and national security threats through corruption of officials and legal systems, undermines free enterprise by crowding out the private sector, and threatens the financial stability of countries and the international free flow of capital". US Department of State, Bureau of International Narcotics and law Enforcement Affairs, Money Laundering and Terrorist Financing: A Global Threat, NARCOTICS ConTroL Reports (2004), available at https://2009-2017.state.gov/j/inl/rls/nrcrpt/2003/vol2/html/29843.html.

5 Organization for Economic Co-operation Development, Official Website, Who we are? OECD (2020), available at https://wrere.oecd.org/about/.

6 Organization for Economic Co-operation Development (OECD), Money Laundering Awareness, Handbook for Tax Examiners and tax Auditors 11 (2009), available at $h t t p: / /$ wrerw.oecd.org/ctp/crime/money-laundering-awareness-handbook-for-tax-examiners-and-tax-auditors.pdf. 
It has been observed, as Lucian noted, ${ }^{7}$ that globalization has allowed a leap for the business of transnational organized crime groups, providing them an ideal environment for business development and ways of obtaining illegal goods gained by opening borders to trade flows. This is why it has been important to set up international instruments in order to combat it from being committed. These include the 40 Recommendations from the Financial Action Task force (FATF), ${ }^{8}$ the United Nations Global Program against Money Laundering, ${ }^{9}$ the Statement of Principles of Prevention of Criminal Use of the Banking System for the Purpose of Money Laundering of the Basel Committee on Banking Regulations and Supervisory Practice, ${ }^{10}$ the 19 recommendations of the Caribbean Financial Action Task Force (CFATF), ${ }^{11}$ the Council of the European Communities on prevention of the

7 Dragoş Lucian Rădulescu, The Concept of Money Laundering in Global Economy, 4 Int. Jour. Tra.

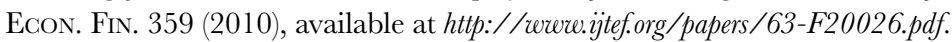

8 "The FATF Recommendations set out a comprehensive and consistent framework of measures which countries should implement in order to combat money laundering and terrorist financing, as well as the financing of proliferation of weapons of mass destruction. Countries have diverse legal, administrative and operational frameworks and different financial systems, and so cannot all take identical measures to counter these threats. The FATF Recommendations, therefore, set an international standard, which countries should implement through measures adapted to their particular circumstances". Financial Action Task Force, Official Website, The FATF Recommendations, FAFT-GAFI (2020), available at fatf-gafi.org/publications/fatfrecommendations/documents/fatf-recommendations.html.

9 "Through the Global Program against Money-Laundering, Proceeds of Crime and the Financing of Terrorism, UNODC assists Governments in confronting criminals who launder the proceeds of crime through the international financial system. It also provides Governments, law enforcement authorities and financial intelligence units with strategies to counter moneylaundering, advises on improved banking and financial policies and assists national financial investigation services. Strategies include granting technical assistance to authorities from developing countries, organizing training workshops, providing training materials and transferring expertise between jurisdictions". U.N. Technical assistance against money-laundering (2020), available at https://wererce.unodc.org/unodc/en/money-laundering/technical-assistance.html?ref=menuside.

10 "The attached Statement is a general statement of ethical principles which encourages banks' management to put in place effective procedures to ensure that all persons conducting business with their institutions are properly identified; that transactions that do not appear legitimate are discouraged; and that cooperation with law enforcement agencies is achieved". Bank of International Settlements, Official Website, Prevention of criminal use of the banking system for the purpose of money-laundering, BIS (2020) available at https://wrere.bis.org/ publ/bcbsc137.html.

11 "In Aruba, representatives of Western Hemisphere countries, in particular from the Caribbean and Central America, convened to develop a common approach to the phenomenon of the laundering of the proceeds of crime. Nineteen recommendations constituting this common approach were formulated. These recommendations, which have specific relevance to the Region were complementary to the original forty recommendations of the Financial Action Task Force (FATF) established by the Group of Seven at the 1989 Paris Summit", Caribbean Financial Action Task Force, CFATF Overview (1992-2020) available at $h$ ttps://wrerrecfatf-gafic. org/index.php/home/cfatf-overview. 
use of the financial system for the purpose of money laundering, ${ }^{12}$ Naples Political Declaration and Global Action Plan, ${ }^{13}$ the Ministerial Communiqué of the Summit of the Americas Conference concerning the Laundering of Proceeds and Instrumentalities of Crime, ${ }^{14}$ the Political Declaration and Action Plan against Money Laundering ${ }^{15}$ and the Convention on Laundering, Search, Seizure and Confiscation of the Proceeds from Crime. ${ }^{16}$

12 "In order to respond to these concerns in the field of money laundering, Council Directive $91 / 308 / \mathrm{EEC}$ of 10 June 1991 on prevention of the use of the financial system for the purpose of money laundering was adopted. It required Member States to prohibit money laundering and to oblige the financial sector, comprising credit institutions and a wide range of other financial institutions, to identify their customers, keep appropriate records, establish internal procedures to train staff and guard against money laundering and to report any indications of money laundering to the competent authorities". Council Directive 2005/60/EC of the European Parliament and Council, 2005, available at https://eur-lex.europa.eu/legal-content/ EN/TXT/?uri=celex:32005L0060.

13 "The fight against organized crime should be accorded high priority by States and by all relevant global and regional organizations, with the necessary support of the general public, the media, business, institutions and non-governmental organizations. Transnational crime threatens the social and economic growth of developing countries and countries in transition, and the international community should assist these countries in their efforts to strengthen criminal justice institutions. States which have not yet become party to the UN Convention against Illicit Traffic in Narcotic Drugs and Psychotropic Substances of 1988 are urged to do so". Naples Political Declaration and Global Action Plan (1994), available at http://wrewenzdl.org/gsdlmod? $e=d-$ 00000-00---off-0cdl--00-0----0-10-0---0---0direct-10---4------0-1l--11-en-50---20-about---00-01-00-0-0-11-1-0utfzz-8-00 $\mathcal{E}^{2} c l=C L 1.139 \mathcal{E}^{2} d=H A S H 4068919759 b 42 c 6 b 335 e c 3.9 .24 \mathcal{E}^{2} \mathrm{gt}=1$.

14 "The Heads of State and Government of the Western Hemisphere agreed at the Summit of the Americas in December 1994, that the was a need for intensified action by all of their Governments, individually and collectively, to address the problem of illicit production and trafficking of drugs and their illegal use, as well as the laundering of the proceeds, property, and instrumentalities used in criminal activities (hereinafter referred to as money laundering)". International Money-Laundering Information Network, Ministerial Conference Concerning the Laundering of Proceeds and Instrumentalities of Crime Ministerial Communiqué (1995), available at https://wwro.imolin.org/imolin/badecl95.html.

15 "Recognizing the political will expressed by the international community, especially as reflected in such initiatives as the Convention on Laundering, Search, Seizure and Confiscation of the Proceeds from Crime, adopted in 1990 by the Committee of Ministers of the Council of Europe, the Ministerial Communiqué of the Summit of the Americas Conference Concerning the Laundering of Proceeds and Instrumentalities of Crime, held at Buenos Aires in December 1995, and by such bodies as the Inter-American Drug Abuse Control Commission of the Organization of American States, the Asia/Pacific Group on Money Laundering, the Caribbean Financial Action Task Force, the Offshore Group of Banking Supervisors and the Commonwealth, all of which are well-recognized multilateral initiatives aimed at combating money-laundering and constitute legal or policy frameworks within which concerned States are defining and adopting measures against money-laundering". International Money-Laundering Information Network, Political Declaration and Action Plan against Money Laundering (1998) available at https://www.imolin.org/imolin/ungadec.html.

16 "The aim of this Convention is to facilitate international co-operation and mutual assistance in investigating crime and tracking down, seizing and confiscating the proceeds thereof. 
Money laundering in Mexico is formally referred to as the crime of Operations involving Resources Derived from Illicit Sources, governed by Articles 400 Bis and 400 Bis 1 of the Federal Criminal Code, stipulating that those who purchase, dispose of, manage, safeguard, possess, exchange, covert, deposit, withdraw, transfer or transport, within or outside the national territory or vice versa, resources or goods of any nature, with the knowledge that said resources are the proceeds of illicit acts are committing said crime. Furthermore, the applicable legal framework links such conduct with national and international terrorism and its financing as set out by Articles 139, 139 Bis, 139 Ter, 139 Quater, 139 Quinqui, 148 Bis, 148 Ter and 148 Quater. It should be noted that despite the fact that these offenses may seem unconnected, Thony ${ }^{17}$ explains that laundering criminal funds aims at giving a legal appearance to dirty money, whereas laundering of terrorist funds aims at obscuring assets of a legal origin, both of which represent the same threats to financial systems and public institutions.

It is also noted that on the basis of international requirements, the Federal Law on the Prevention and Identification of Transactions of Illicit Resources was passed in 2012, in an effort to protect the financial system and the Mexican economy. By establishing measures and procedures to prevent and detect acts or transactions involving resources of illicit origin, it draws on inter-institutional coordination to pursue useful elements to investigate and prosecute crimes, the financial structures of criminal organizations while preventing the use of resources for financing criminal activities. In addition, said law has its accompanying regulations and general rules regarding anti-money laundering activities, both of which were published in 2013.

Financial institutions have also had to adapt to the new guidelines. According to the Vice-presidency for Supervision and Preventive Processes, which acts as an administrative unit attached to the Mexican National Banking Securities Commission $(\mathrm{CNBV}),{ }^{18}$ the three stages of money laundering ${ }^{19}$

The Convention is intended to assist States in attaining a similar degree of efficiency even in the absence of full legislative harmony. Parties undertake in particular: to criminalize the laundering of the proceeds of crime and to confiscate and proceeds (or property the value of which corresponds to such proceeds)". Council of Europe Portal, Convention on Laundering, Search, Seizure and Confiscation of the Proceeds from Crime (1993) available at https://wrerc.coe.int/en/ web/conventions/full-list/-/conventions/treaty/141.

17 Jean-Francois Thony, Money Laundering and Terrorism Financing: An Overview, 3 Cur. Dev. Mon. Fin. L., International Monetary Fund, 4 (2005), available at https://wrere.imf.org/exter nal/np/leg/sem/2002/cdmfl/eng/thony.pdf.

18 Vice-presidency for Supervision and Preventive Processes, Money Laundering, National Banking and Securities Commission (CNBV) (2019) available at https://wrere.gob.mx/cms/up loads/attachment/file/71151/VSPP_Lavado_de_Dinero__130701.pdf.

19 "Stage 1, Criminals proceeds are transferred to, or collected by, the professional money launderer; Stage 2, Professional money launderers execute layering stage; Stage 3, Laundered funds are handed back to clients for investment or asset acquisition". Financial Action Task Force, General Business Model of Professional Money Laundering Networks, Faft Report Professional 
have been recognized in Mexico: first there is the placement stage, in which the criminal deposits its illicit proceeds into the financial system; this sets the scene for the second stage called layering or stratification where financial transactions are made with these ill-gotten gains to change its appearance and hinder its being traced; and the third one is the integration, which introduces illegally obtained funds into economy by pretending to be legitimate. The distinction of the above stages provides information as to criminals' modus operandi to then be able to establish mechanisms to prevent and combat the crime of Operations involving Resources Derived from Illicit Sources, with the Financial Intelligence Unit in charge of this task on Mexican soil. ${ }^{20}$

\section{The Role of the Mexican Notary in the Fight Against the Crime of Money Laundering}

To begin this chapter, it must be pointed out that the Mexican Notariat has the characteristics of the Latin Notary System, whose main function according to De Prada ${ }^{21}$ is to have a professional, independent, legal and impartial expert involved in legal transactions by providing legal transactions with certainty in such a way that whoever acquires property is most likely to do so safely. The Latin system is differentiated from others by notaries' high-level of legal education. Since 1948, the Mexican Notariat has belonged to the International Union of Latin Notaries, ${ }^{22}$ which according

Money LaUndering, 17 (2018) available at HTTP://WWW.FATF-GAFI.ORG/MEDIA/FATF/DOGUMENTs/Professional-Money-Laundering.PDF.

20 Financial Intelligence Unit, Official Website, About us, UIF (2020) available at https:// wrere.uif.gob.mx/es/uif/quienes_somos.

21 José Ma. De Prada, Los Sistemas Notariales Anglosajón y Latino. 106 Revista DE Derecho NoTARIAL 90,108 (1994), available at http://historico.juridicas.unam.mx/publica/librev/rev/dernotmx/ cont/106/est/est7.pdf.

22 "The International Union of Notaries (UINL) is a non-governmental organization. It aims to promote, coordinate and further the role and activities of notaries throughout the world. It advocates for their dignity and independence in order to provide a better service to people and society in general. Formed by 19 countries at the time of its establishment in 1948, the organization includes 88 countries by October 2, 2018, of which 22 of the 28 member countries of the European Union and 15 of the 19 countries of the G20, thus showing the spread of the European legal system. Today it is having a presence in almost 120 countries, totaling $2 / 3$ of the world population and accounting for over $60 \%$ of the world's Gross Domestic Product. Directed by a Steering Committee of 28 councilors, the decision-making body is the General Meeting of member notariats where each country has one vote regardless of its importance. It also has a General Council with 176 members and continental and intercontinental commissions working from scientific (vocational training and research), strategic (development), economic (networks and activities) and sociological (human rights and social protection) standpoints". International Union of Notaries, Official Website, Mission (UINL) (2020) available at https://wwrenotariado.org/liferay/web/notariado/el-notario/el-notariado-en-el-mundo/uinl. 
to López, ${ }^{23}$ a notary is the legal professional in charge of a public service that receives, interprets and gives legal form to the free will of the parties, drafting instruments suited to the purpose requested, conferring them authenticity, preserving the originals of such documents, and issuing copies attesting to their content.

Regarding money laundering, it is noted that the Federal Law on the Prevention and Identification of Transactions of Illicit Resources considers notarial role as a vulnerable activity under the terms of Article 17, Section XII, which provides that notaries must notify the Financial Intelligence Unit of operations that requestors agree upon in a notary's presence regarding transfers or creation of real estate property rights (except for guarantees to financial institutions or public housing agencies); of granting powers of attorney for acts of administration and dominion given irrevocably; the incorporation of legal entities, modifications to their assets resulting from the increase or decrease in capital stock, mergers or spin-offs, the sale of shares or equity interests of such entities; of the establishment or modification of property ownership or collateral trusts; and of granting mutual contracts, mortgagebacked or not, in which the creditor is not part of the financial system or public housing agencies.

This has given rise to obligations for the Mexican Notariat, such as compiling user identification files by verifying credentials or official documentation and collecting copies; requesting for information as to whether the user is aware of the existence of beneficial ownership; presenting official documentation to identify inquiries into the business relationship with the subject; compiling a transaction profile; submitting notification of vulnerable activities to the Financial Intelligence Unit; ${ }^{24}$ sending vulnerable business notifications through the Mexican Tax Administration Service (SAT), except for those doing so by means of the electronic system for sending declarations under federal tax provisions and providing the necessary facilities for verification visits in order to comply with the provisions of the Federal Law on the Prevention and Iden-

23 Fortino López Legazpi, El Notario y el Mundo de Hoy, 34 Rev. Der. Not. Mex., 15 (1968), available at http://historico.juridicas.unam.mx/publica/librev/rev/dernotmx/cont/34/cnt/cnt2.pdf.

24 "Notices shall be submitted by electronic means and in the office, format established by the Secretary. Such notices shall contain in respect of the act or operation related to the vulnerable activity reported, the following: I. General Data of the person performing the vulnerable activity; II. General data of the user or the beneficial ownership and information on their activity and occupation in accordance with Article 18, Fraction II, of this Law; and III. General description of the Vulnerable Activity for which it is notified. Notaries and Public Brokers shall be considered to satisfied with the obligations to submit the relevant notices using the electronic system by which they report or submit declarations and notices to comply federal tax provisions". Ley Federal para la Prevención e Identificación de Operaciones con Recursos de Procedencia Ilícita [LFPIORPI] [Federal Law on the Prevention and Identification of Transactions of Illicit Resources], as amended, Article 24, Diario Oficial de la Federación [D.O.F], october 17, 2012 (Mex.). 
tification of Transactions of Illicit Resources, the Regulation and General Rules Governing the Prevention of Money Laundering. ${ }^{25}$

In addition to the obligations in the preceding paragraph are those related to the identification of the form of payment and restrictions on the use of cash in property transactions that notaries record in their notarial acts by informing users of these limitations and subsequently requesting the necessary documentation that supports the payment of the property. Of particular note is Article 32 of the Federal Law on the Prevention and Identification of Transactions of Illicit Resources, which provides that settling, paying or accepting cash payment, whether in national or international currencies or precious metals, in the creation or transmission of rights in real estate greater in value than or equivalent to $8,025 U M A S,{ }^{26}$ on the day the payment is made or the obligation is fulfilled is prohibited.

Complementing the above, in accordance with Article 33 of the same law, notaries are requested to identify how users pay each other. This consideration arises from contracts signed for values greater than or equivalent to 8,025UMAS, even though when the transaction value is less than the abovementioned amount or when the act or operation has been paid in full or in part prior to signing the instrument, it is enough for the users to swear to a statement of truth. This situation is also mentioned in Article 45 of the Regulation of the Federal Law on the Prevention and Identification of Transactions of Illicit Resources, providing that the notary must consider the date and the form of payment the transaction is carried out.

The imposition of anti-money-laundering obligations on the Notariat is not exclusive to the Mexican State. In fact, it follows European models, ${ }^{27}$ particularly the one launched in Spain, which is considered the epitome of

25 Money Laundering Prevention Portal, Official Website, Public Faith, Notaries and Public Brokers (2020), available at https://wrww.pld.hacienda.gob.mx/work/models/PLD/documentos/actividades/ act fep.pdf.

26 "The Unit of Measurement and Updating (UMA) is the economic reference in Mexican pesos to determine the amount of payment of the obligations and assumptions provided for in the Federal Laws, of the Federative Entity, as well as in the legal provisions emanating from all previous one". National Institute of Geography and Statistics (INEGI), Unit of Measuring and Updating (UMA) (2020) available at https://wrere.inegi.org.mx/temas/uma.

27 "On 8 July 2019, the Financial Action Task Force (FATF) published its new Guidance for a Risk-Based Approach for Legal Professionals. The previous edition was released in 20072008. "The AML system used by Spain's notaries represents a considerable advance for Public Authorities", the FATF notes. "All parties subject to AML requirements may consult the Beneficial Ownership Database (Base de Datos de Titular Real, BDTR)", it highlights. The FATF proposes a series of measures to Governments aimed at combating money laundering and terrorist financing and protecting the integrity of the international financial system. These measures include a model to be followed by the money laundering prevention system employed by notaries in Spain, and more specifically its BDTR. The Guidance has been sent to the 39 countries that form part of the FATF, including Spain, as well as to member associations such as the European Union". Notaries of Europe, The FAFT highlights the role of the notarial system in 
good notarial practice around the world. But the main difference between the mandatory burden of both countries is that the Spanish Notariat has all the tools needed to accomplish the task since it has benefited from the adequate technological infrastructure, resource management and implementation of effective electronic platforms, all of which Mexico lacks:

The Centralized Organization for the Prevention of Money Laundering (OCP) is the main structure the Spanish Notariat has in place to combat economic crime. Its creation, by the Order EHA 2963/2005, made it possible to intensify and channel the collaboration of notaries in this field with public authorities and judicial and police authorities. The technicians of the Centralized Organization for the Prevention of Money Laundering perform their work by analyzing and crossing-referencing data (always in the context of Spanish data protection regulations), thanks to the fact that operations carried out by notaries are parameterized and stored in the Single Computerized Notarial Index, a powerful database created by the Notariat in 2004. They also receive alerts and notices from notaries themselves about transactions that seem suspicious to them, which they trace and investigate thoroughly. ${ }^{28}$

Taking the above into consideration, it is possible to say that the use of media and technological infrastructure makes easy to fulfill the obligations assigned and to detect subjects or transactions that could be considered suspicious. When placed in the context of Mexico, it shows the complexities the Mexican Notariat faces every day, for complying with the mandatory burden, using only criteria issued by the authority and information provided through the Financial Intelligence Unit; like Terrorist Resolutions and Proliferating Weapons of Mass Destruction emitted by United Nations Security Council, as well as the updated list referred to in the Financial Intelligence Holder Agreement, which makes known to the general public the list of persons and entities within the lists of the Resolutions 1267 (1999) and their succession, 1373 (2001) and the others that are issued by United Nations Security Council in basis of United Nations Charter. ${ }^{29}$ This indicates that in absence of technological infrastructure and other media by which the anti-money laundering obligations being imposed can be fulfilled, the Mexican Notariat usually responds by holding sustained conversations with notarial guilds and asking the authority for criteria that will subsequently be published on the Tax Ad-

the fight against money laundering, CNEU News (July 23, 2019), available at http://werere.notaries-ofeurope.eu/index.php?pageID=17370.

28 Centralized Organization for the Prevention of Money Laundering, The collaboration of notaries in the prevention of money laundering, terrorist financing and tax fraud, OCP NOTARIADO, 1 (2007), available at http://wrerrenotariado.org/liferay/c/document_library/get_file:p_l_id $=15943061$ GoroupId $=10218$ \&folderId $=15943630$ Bname $=$ DLFE-334444.pdf.

29 Money Laundering Prevention Portal, Official Website, United Nations Security Council Resolutions and Updated List (2020), available at https://sppld.sat.gob.mx/pld/interiores/actualizacion listas.html. 
ministration Service's (SAT) electronic platforms as frequently asked questions. ${ }^{30}$ These generally refer to the material impossibility of fulfilling certain obligations because of the lack of interpretations of the law or regulatory provisions to enforce the rule, or even because of the lack of knowledge and expertise in fields outside notarial practice indirectly involved in complying with said obligations.

This situation leads to placing the notary in a complicated situation, which usually end in abstaining from the providing the service. ${ }^{31}$ There is a real fear of infringing anti-money laundering provisions because the penalties to which they might be creditors are serious. According to Article 58 of the Federal Law on the Prevention and Identification of Transactions of Illicit Resources, when the offender of the provision is a Notary Public, the Ministry will inform the authority in charge of monitoring the notarial function of the infraction committed so that the offender is removed from office and revoked from the fiat. Possible causes of infringement are recidivism for non-compliance of the mandatory burden, delivery of notices to the Financial Intelligence Unit after the deadline or without meeting the exact requirements and allowing users to pay for their benefits in cash when it is prohibited.

It is also seen that, in addition to the loss of the charge, fines may also be added to the pain, which, in accordance with Article 54, are to be applied at the authority's discretion depending on the seriousness of the offence. This may range from 200 UMAS to 100 percent of the value of the property or transaction in question. To this end, according to Article 60, the authority will take into account recidivism of the infringement and the causes, considering it a serious violation if the notary has committed a similar transgression within a two-year period.

Finally, it is important to note that under Article 62, the notary could also be sentenced to prison if their conduct were considered to have been intentional.

\section{Dimensions of the Problem And its Turning Points}

In the last chapters, the components of money laundering that cause global affectations were identified, and the mandatory burden set out for the Mexi-

30 Money Laundering Prevention Portal, Official Website, Frequently Asked Questions and Criteria (2020) available at https://sppld.sat.gob.mx/pld/interiores/preguntas.html.

31 In Mexico, each state has its own notarial legislation, which has been adapted in accordance with the legal framework of anti-money laundering. It is observed, to give an example, that in Queretaro, Article 69 of the Notaries Public Law states that the notary must ensure that the documentation and information that users provide reflects a consistent legal reality and if the data is ambiguous, inconsistent, contradictory or insufficient, the notary must refrain from providing the service. 
can Notariat was explained with special reference to the possible penalties that may be applied if notaries do not comply with the provisions that establish mechanisms to prevent and mitigate the crime. Therefore, this section analyzes the factual, regulatory and axiological dimensions surrounding the issue object of this note as well as its turning points:

About the factual dimension, it is observed that within daily notarial activity there is some difficulty in complying with the mandatory burden established in the anti-money laundering provisions due to the lack of technological and human infrastructure identified above. Even though the notarial service provided is personal, it is materially impossible for the notary by himself to fulfill all the obligations and responsibilities established for each of the transactions left on record.

On the other hand, it is clear that the relationship with clients has modified because they feel uncomfortable about the disclosure and investigation of personal information, the submission of the documentation requested by law to put together the transactional profile of the subject, knowledge of the existence of beneficial ownership and the creation of the user identification file. Likewise, there is the complexity of complying with the obligation of verifying the clients' documentation without a technological infrastructure where data can be compared. Furthermore, there is a lack of inter-institutional collaboration that allows sharing databases. Therefore, the Notariat has seen the need to ask the authority on several occasions for the criteria that guides it so as not to commit any infraction of the anti-money laundering regulations since notaries are aware of the limitations due the lack of graphoscopic and psycho-morphological studies, as well as the biometric instruments ${ }^{32}$ that would allow them to indisputably recognize the person they claim to be.

In the regulatory dimension, the lack of normative precision and its regulatory provisions are identified as causes that have the Mexican Notariat waiting for interpretations and possible criteria presented by the authorities. In the same way, notarial activity is compromised when, derived from the obligations, the notary must refrain from providing service on the mere suspicion of irregularity in the identification data clients may present, in addition to the fear of relapsing into any of the planned sanctions.

Finally, in the axiological dimension, it is observed that fulfilling a contract could cause a lack of compliance with Notarial Deontology, which, among

32 Through Bulletin 5513, the Chamber of Deputies of the Mexican Government communicated on December 3, 2020, the approval of the new General Population Act, in which the creation of the "Unique Digital Identity Card" is provided; it will serve as an official identification document before the authorities, inside and outside Mexican territory. However, it is noted that the General Directorate for the Registration of the Population and Identity has planned its implementation in a 4-year range, so in the meantime, measures that may be applicable at present must be taken. Government of Mexico, National Population Register (RENAPO), What we do? (2020), available at https://wrwe.gob.mx/segob\%7Crenapo/que-hacemos. 
other things, establishes the principle of confidentiality that could be compromised by complying with the notary's obligation to identify how users pay each other. This consideration arises from the contracts they subscribe since their bank account data is exposed in the public document; due to its notarial nature, it is subject to reproductions. In addition, there is the principle of impartiality and independence, ${ }^{33}$ which establishes the need for the notary to avoid any form of discrimination against clients, leaving the notary in a dilemma by refusing to provide notarial service when clients apparently do not meet the administrative requirements established for identification documents or when they do not have bank accounts to comply with the restriction on the use of cash in real estate transactions.

\section{Conclusions}

This note has explained the worldwide importance of the fight against money laundering, as well as the effort made by different organizations in the implementation of legal instruments that seek to mitigate and prevent the crime, positioning the Notarial System as a key element to achieve the objectives set nationally and internationally. Particularly, the object of study focused on the analysis of the role of the Mexican Notariat inside the process of mitigation and prevention of this crime, explaining the mandatory burden of anti-money laundering and the penalties to which notaries may receive in the event of non-compliance. The note concludes that although the notary has been placed in a strategic point in the fight, the necessary elements have not been provided for notaries to carry out the work efficiently. These include, among others, technological and human infrastructure, clear and consistent regulations, as well as fixed and rough guiding criteria established by the authority that clearly dictate a way to comply with the guidelines.

This is how the factual, normative and axiological consequences that anti-money laundering provisions within the notarial activity are notified; highlighting the fact that the ideal scenario would be having the Mexican State providing an electronic system with a database made available exclusively for Mexican Notariat consultation as it is done in the Spanish model. Due to the situation the country is experiencing, one proposal is to at least establish inter-institutional work with government entities and the participation of private ones, which have biometric information and means of citizen identification, such as, among others, the National Electoral Institute (INE) and banking institutions. Similarly, the regulatory conflict that has been discussed makes it possible to conclude that there are no clear and precise provisions on the matter. The inconsistency between the severity

33 International Union of Notaries, Official Website, Principles of notarial ethics (UINL) (2020), available at https://wrere.uinl.org/principios-de-deontologia. 
of the sanctions that may be applied is also highlighted since the Mexican $\mathcal{N}$ otariat is a key piece for assisting in the fight against money laundering and not the enemy to be defeated.

To sum up, the complexity that permeates the field of axiology, leaves the non-observation of the principles that govern the notarial essence to comply with the money-laundering framework latent. 